\title{
The Evolution of Forms of Water Users Organizations in California
}

\author{
Albert T. Henley* \\ I \\ DIVERSITY OF FORMS
}

The statutory means available to Californians to acquire, conserve, or distribute water as public corporations are many and varied. ${ }^{1}$ There are hundreds of public water organizations now existing in this state ${ }^{2}$ and there are more to come. Of these the vast majority are organized under established and familiar general statutes. No more than forty were created by or organized under special district acts.

Special act districts are a fairly recent development, not to say fashion, in legislation. The dominating group here is the county-wide type, usually titled "county flood control," or "county flood control and water conservation" districts. All of them reflect generally the first statute, which was the Los Angeles County Flood Control Act, enacted in 1915. ${ }^{3}$ Not until twelve years later was that lead followed in a neighboring county when, in 1927, the Orange County Flood Control Act was made law. Another twelve years passed and in 1939 the San Bernardino County Flood Control District was formed by a special act. ${ }^{5}$ Thereafter, in the ten-year period of the 40 's such districts were formed in the following nine counties: Ventura, ${ }^{6}$ San Luis Obispo, ${ }^{7}$ San Diego, ${ }^{8}$ Riverside, ${ }^{9}$ Humboldt, ${ }^{10}$ Monterey, ${ }^{11}$ Mendocino, ${ }^{12}$

* Member, San Jose Bar.

1 See Cal. Dep't of Public Works, Div. of Water Resources, Generat Comparison of CaLIFornia WaTer Distruct Acts (1955).

${ }^{2}$ See Cal. Water Resources Bd., Butr. No. 2, Water Utiltzation and Requirements of Caltfornta, App. B, Directory of Water Service Agencies in Caitfornta (1955).

31 CAL. WATER CODe ANN., act 4463 (Deering 1954), as amended (Supp. 1957).

41 Cal. Water Code ANn., act 5682 (Deering 1954), as amended (Supp. 1957).

51 CAL. Water Code ANN., act 6850 (Deering 1954), as amended (Supp. 1957).

6 Ventura County Flood Control Act, 1 CAL. WATER Code ANN., act 8955 (Deering 1954), as amended (Supp. 1957).

${ }^{7}$ San Luis Obispo County Flood Control and Water Conservation District Act, I CaL. WATER CODE ANN, act 7205 (Deering 1954).

8 San Diego County Flood Control District Act, 1 Cal. Water Code ANn., act 6914 (Deering 1954).

9 Riverside County Flood Control and Water Conservation District Act, 1 CAL. WaTER Code ANv., act 6642 (Deering 1954), as amended (Supp. 1957).

10 Humboldt County Flood Control District Act, I CAL. Watre Code AnN., act 3515 (Deering 1954), as amended (Supp. 1957).

11 Monterey County Flood Control and Water Conservation District Act, 1 CAL. WATER CODE ANN., act 5064 (Deering 1954), as amended (Supp. 1957).

12 Mendocino County Flood Control and Water Conservation District Act, 1 CaL. WATER Code AnN., act 4830 (Deering 1954). 
Alameda ${ }^{13}$ and Sonoma. ${ }^{14}$ In the single, busy legislative year of 1951 six county flood control and water conservation districts appeared. These are in Contra Costa ${ }^{15}$ Lake $,{ }^{16} \mathrm{Napa},{ }^{17}$ Santa Clara ${ }^{18}$ Solano, ${ }^{19}$ and Yolo ${ }^{20}$ counties. In 1953 districts of this kind were created in Marin County ${ }^{21}$ and San Benito County, ${ }^{22}$ and in 1955 in Del Norte, ${ }^{23}$ Santa Barbara, ${ }^{24}$ and Santa $\mathrm{Cruz}^{25}$ counties. In the 1956 extraordinary session of the legislature San Joaquin County was added to the list..$^{26}$ In 1957 two more special districts in Placer County ${ }^{27}$ and Tehama County ${ }^{28}$ were created.

Three tendencies are noticeable. One is that the movement proceeded from south to north, with a few exceptions; another is a tremendous increase in velocity in recent years; and the third is the relative emphasis on flood control. All follow naturally from pressures of need created and felt by an expanding and demanding citizenry. All show a general similarity in structure and in powers-indeed they were certainly largely copied one from another. They are county-wide in area (Los Angeles, San Benito, and Yolo are exceptions); they are divided or divisible into zones of benefit for project financing; they are governed, ex-officio, by their county supervisors; they may incur bonded indebtedness by zones (San Diego is an exception) by two-thirds vote therein (Los Angeles requires only a majority), and all have the primary purpose of flood control, with the additional purpose of conservation of waters so controlled.

\footnotetext{
13 Alameda County Flood Control and Water Conservation District Act, I CAC. Water Code ANn., act 205 (Deering 1954), as amended (Supp. 1957).

14 Sonoma County Flood Control and Water Conservation District Act, 1 CAc. Whiter Cone ANv., act 7757 (Deering 1954), as amended (Supp. 1957).

15 Contra Costa County Flood Control and Water Conservation District Act, 1 Cax. WATER CODE ANN., act 1656 (Deering 1954), as amended (Supp. 1957).

${ }^{16}$ Lake County Flood Control and Water Conservation District Act, 1 Cat. Warer Cone Awr., act 4145 (Deering 1954), as amended (Supp. 1957).

17 Napa County Flood Control and Water Conservation District Act, 1 CAL. Water Cods Ars., act 5275 (Deering 1954), as amended (Supp. 1957).

18 Santa Clara County Flood Control and Water Conservation District Act, 1 Cat. Water CODE ANN., act 7335 (Deering 1954), as amended (Supp. 1957).

19 Solano County Flood Control and Water Conservation District Act, 1 CAT. Water Code Avs., act 7733 (Deering 1954), as amended (Supp. 1957).

20 Yolo County Flood Control and Water Conservation District Act, 1 Cax. Water Code ANs., act 9307 (Deering 1954).

21 Marin County Flood Control and Water Conservation District Act, 1 Cat. Water Code ANN., act 4599 (Deering Supp. 1957).

${ }^{22}$ San Benito County Water Conservation and Flood Control District Act, 1 Car. WaTER Code ANN., act 6808 (Deering 1954), as amended (Supp. 1957).

23 Del Norte County Flood Control District Act, 1 CaL. Water Code ANw., act 2040

(Deering Supp. 1957).

24 Santa Barbara County Flood Control and Water Conservation District Act, 1 Cat.

Water Code ANN., act 7304 (Deering Supp. 1957).

${ }^{25}$ Santa Cruz County Flood Control and Water Conservation District Act, 1 Car. WhTER Code ANN., act 7390 (Deering Supp. 1957).

${ }^{26}$ San Joaquin County Flood Control and Water Conservation District Act, 1 Cat. Water

Code Aws., act 7150 (Deering Supp. 1957).
} 
The remaining special district acts are truly special in every sense. They appear to have been tailored to particular specifications. The only general statement possible is that with the exception of the American River Flood Control District Act ${ }^{29}$ and the Orange County Water District Act, ${ }^{30}$ all are very new, having been created in 1950 or thereafter.

By contrast, the thirty-two presently existing general district acts are for the most part long-established. Only four were passed in the last twenty years. One of these four-Water Replenishment District Act ${ }^{3 x}$-is not truly general, being confined to seven southern counties. ${ }^{32}$ And of the remaining three, only one, the Community Services District Law, ${ }^{33}$ lias had any apparent use.

With regard to general act districts, it is certain that both in area and in accomplishment the irrigation districts of this state dominate the field of water management. There can be no doubt that the discovery of the legal formula for these organizations was of infinitely greater value to California than the discovery of gold a generation before. They are an extraordinarily potent engine for the creation of wealth. There are some 112 irrigation districts in existence now, ${ }^{34}$ but this represents no recent growth. According to the Department of Public Works, there were in 1925 more than 107 irrigation districts then functioning in California. ${ }^{35}$

A review, in chronological order, of those of the general district acts which seem to have been found the most useful shows that the evolution of water management organizations has followed with fair accuracy the changing character of the state itself. We begin with reclamation districts in $1866 .{ }^{36}$ This is a form which could be expected in a new, raw land. Their function is to reclaim swamps, marshes, or tidelands-that is, to reduce them from a natural to a useable state. Such districts exist today in large numbers. I have been unable to secure an accurate figure but a guess is that

27 Placer County Water Agency, 1 CAI. Water Code ANN., act 5935 (Deering Supp. 1957).

28 Tehama County Flood Control and Water Conservation District Act, 1 CAL. WaTER Code ANN., act 8510 (Deering Supp. 1957).

291 CAI. WATER Code ANN., act 320 (Deering 1954), as amended (Supp. 1957).

301 CAL. WATER CODE ANN., act 5683 (Deering 1954), as amended (Supp. 1957).

31 CaL. Water CODE $\$ \S 60000-449$.

32 Santa Barbara, Ventura, Los Angeles, San Diego, Riverside, San Bernardino, and Orarge. Cat. WVater Code $\S 60047$.

33 CAT. Govt. Code $\$ \S 61000-891$.

34 See Cat. Water Resources Bd., Butl. No. 2, Water Utilization and Requirements of Calmfornia, App. B, Directory of Water Service Agencies in CaLtfornia (1955). See also Cat. Dep't of Publtc Works, Div. of Water Resources, Bule. No. 21-P, Report on Irrigation Districts in Cattrornta 1944-1950

35 Cat. Dep't of Public Works, Div, of Engineering and Irrtgation, Bult. No. 10 (1925).

${ }^{36}$ Cal. Stat. $1865-66$, c. 570 . See also Cal. Stat. $1867-68$, c. $415, \$ 30$. The reclamation district law is now codified as CAL. WATER CODE $\$ \S 50000-3901$. 
there may be as many as 250 . They perform essential work, particularly in the region of the Sacramento-San Joaquin river system.

Having the same general purpose are three types of protection district acts $^{37}$ and three types of drainage district acts, ${ }^{38}$ which were first enacted in 1880 and 1885 , respectively.

There followed, in 1897, the important irrigation district act, previously mentioned. That act, called the "Wright-Bridgeford Act," original Wright Act, which had been passed in 1887, ten years before. ${ }^{40}$ Here the principal endeavor, of course, was to put water to agricultural use. Powers were adequate for securing a water supply and furnishing it to included lands.

Growing population concentrations and the municipal ownership movement of the Progressive Republican period cooperated to produce enactment of the Municipal Water District Act of $1911 .{ }^{41}$ Districts of this kind are concerned primarily with a domestic water supply. To fill a need for organizations having a more general, all-inclusive, purpose two acts were passed in 1913, namely the County Water District Law ${ }^{42}$ and the California Water District Law. ${ }^{43}$ Of the two, a great deal more use has been made of the former. Both statutes declare that districts created under them may have the functions of drainage and reclamation in combination with those of securing and distributing water for both domestic and irrigation uses.

In 1921 two more general laws were enacted. They were the Municipal Utility District Act ${ }^{44}$ and the Public Utility District Act. ${ }^{45}$ Here water management is no longer the sole or necessarily the dominant objective. Such districts may be concerned with the furnishing of general utility services, even including telephone service, to their inhabitants.

As the pressure of demand upon supply grew during the '20's, and comcided with periods of reduced precipitation, the words "water conservation" acquired currency. The "Water Conservation Act of 1927"40 was

37 Protection District Act of 1880, 1 CAT. WATER Code Ars., act 6172 (Deering 1954), as amended (Supp. 1957); Protection District Act of 1895, 1 CaL. WaTER Code ANs., act 6174 (Deering 1954); Protection District Act of 1907, 1 CAL. WATER Code ANN., act 6175 (Deering 1954).

38 Drainage Law of 1885, 1 Car. WATER Code ANN., act 2200 (Deering 1954); Drainage District Act of 1903, 1 Car. WATER CODE ANN., act 2202 (Deering 1954); Drainage District Improvement Act of 1919, I CAr. WATER CoDE ANn., act 2203 (Deering 1954).

${ }^{39}$ Cal. Stat. 1897, c. 189. The Irrigation District Law is now codified as CaL. WatzR Code $\$ \S 20500-9978$.

40 Cal. Stat. 1887 , c. 34.

41 CAL. WATER Code ANn., act 5243 (Deering 1954), as amended (Supp. 1957).

12 Cal. Stat. 1913, c. 592, now codified as CAI. WATER CODE $\$ \$ 3000-3901$.

43 Cal. Stat. 1913, c. 387, now codified as CAL. WATER CODE $\$ \$ 34000-8501$.

$\$ 4$ CAT. PUB. Ur. CODE $\$ \$ 11501-4509$.

45 Id. $\$ \$ 15501-7776$.

461 Cax. Water Code Ann., act 9127a (Deering 1954), as amended (Supp. 1957). 
passed, followed by the "Water Conservation Act of 1929" 47 which, upon reenactment, became known as the "Water Conservation Act of 1931." "48 The districts created by these acts, particularly the latter, look to the financing and construction of conservation works as their main objectives.

In 1951 important legislation was enacted in apparent response to the need for providing services, including a water supply, to areas relatively thickly settled, but without a nunicipal organization. This is the Community Services District Law. ${ }^{48}$

It can be seen from the foregoing brief review that the history of water management organization laws provides a rough parallel of the evolution of California froin a true frontier through a period of agricultural dominance, with rival municipal demands, to one of relative balance in which the influence of the needs of suburbs and industries is clearly felt. And, as the problem to be solved became more complex in recent years, so grew the tendency to write special legislation to solve it.

II FACTORS INFLUENCING FORM AND POWER

How did these statutes cone to take just the form they have? History indicates, as we have seen, that the most important factor here is the character and relative pressure of the need for water. But other influences bear iniportantly when it comes to actually drafting the law. An excellent example of this is to be found in the history of the enactnient of one particular law, the Water Conservation Act of $1931{ }^{50} \mathrm{I}$ am fortunately placed to study this legislation because it was brought into existence by my senior associate, Herbert $\mathrm{C}$. Jones, then a nember of the California Senate.

We begin with the need for legislation as seen by the organizers. Efforts to conserve water began in the Santa Clara Valley, which lies at the southern end of San Francisco Bay, in 1913, and resulted directly from the alarming drop in the underground water levels upon which the orchardists relied. The first World War put a stop to these tentative steps, but thereafter, the situation having worsened, the agitation was taken up by a small, dedicated group whose main problem was to convince the inass of the farmers and the public that the ground water strata could be artificially recharged. To this end, a comprehensive engineering study and report was made, followed by a nunber of experiments with simple spreading works, designed to induce additional percolation in the streain beds.

It wasn't enough. The first provision for a district defined its boundaries

47 Cal. Stat. 1929, c. 166.

481 CaL. WATER CODE ANN, act 9127c (Deering 1954), as amended (Supp. 1957).

49 Car. Govt. Code $\$ \$ 61000-891$.

501 CaL. Water Code ANN., act 9127c (Deering 1954), as amended (Supp. 1957). 
as including all of the county. This was in 1921. The necessary election within the proposed district failed. The proponents tried again in 1923, this time eliminating areas to the north and the south of the county, in which resistance had seemed most adamant. Time had, however, served the unconvinced and the idea of a public water conservation agency was defeated by a vote of inore than seven to one. In 1929 a third attempt was crowned with success. The legislature passed the general act known as "The Water Conservation Act of 1929 "51 and the election in a portion of northern Santa Clara County to organize the first district thereunder secured an approving vote of approximately nine to one.

It is instructive to consider the reasons for such a reversal of sentiment in the space of six years. One reason is that, in the interim, sufficient data on the positive value of artificially-mduced percolation was gathered and publicized to convince all but the most invincibly wrong-headed. Another is that support in the legislature and in his home county had been carefully nurtured by Senator Jones, who authored the act. A third is that the boundaries described $i m$ the formation election had been realistically drawn with reference to probable benefit. A fourth reason is found in the provisions of the statute itself. For example, city people were able to note that the district's ad valorem tax bore on land alone, exclusive of improvements, while the farmers were assisted in carrying the burden by the fact that all lands, including the more highly-valued plots of the city dwellers, were taxed. It was felt that the farmers had the most direct interest in the district and should not properly be demed influence in its operations. This was accomplished by providing that directors be chosen from divisions equal in area but not necessarily in population. Fears as to the extent of the possible taxing power were allayed by limiting it to fifteen cents on eacl $\$ 100$ of assessed value of land alone (this has recently been raised to twenty-five cents), and by making no provision for bonds.

The essential element of bonding power to finance capital expenditures was added in $1931 .^{52}$ This amendment became possible only because of changed popular sentiment regarding water conservation resulting from the fact that its absolute necessity in our semi-arid land was finally becoming generally known. ${ }^{53}$

The recounting of some of the history of the statute we now know as

51 Cal. Stat. 1929, c. 166.

521 Cat. WaTer Code ANN., act 9127c, $\$ 36$ (Deering 1954).

53 An amendment to the California Constitution of the greatest importance should be mentioned at this time. The amendment added water conservation districts to the list of public agencies in Cahfornia which have the power to take immediate possession of lands required for rights of way or reservoir purposes upon filing a condemnation action and depositing in court such security in the way of money as the court may direct. This amendment was proposed in the 1933 legislature and statewide popular approval was secured in the 1934 election. CAI. Const. art. I, § 14. 
the "Water Conservation Act of 1931" has not been given to record the glory of a particular district to which I am sentimentally and professionally tied but rather, as previously mentioned, to illustrate the main factors which directly influence the growth of legislation of this kind. One of the most important factors is a public awareness of the value of the work proposed to be done, to which an intensive campaign of education is an absolutely essential condition precedent. Another essential factor is a demonstrable relationship between the area taxed and the foreseeable benefit to be derived plus a scheme of voting which vests control in the group, whether major landowners, landowners generally, or all electors without distinction, which should equitably have it. A careful choice of the legislative body to govern the proposed agency and a realistic limit upon taxing power also have an effect on the growth of water district legislation. In addition it is important to have a set of powers and purposes adequate to the work to be done; but they must not be so himitless as to stir the opposition of the legislature or most important, the opposition of the voters who must approve and support the district. In this connection, also, the constitutional requirements of notice and hearing prior to formation must be borne in mind.

\section{III}

\section{CHOOSING AN ORGANIZATION}

To move from the past to the present or future, let us assume that an area desires to organize itself for purposes of water management. The first necessary decision will be whether an existing general act will fit the need or whether special legislation must be sought. In the latter event the finished act will probably represent a compromise between an enumeration of powers, rights, and duties which, on the one hand, the proponents feel they need and those, on the other hand, which constitutional requirements, the legislators and, in the last analysis, the electors of the proposed district will allow them to have. Some powers are no longer easy to get. This is true, for example, of the right to deal in electrical energy. Except for such considerations, special legislation may be drawn to meet the heart's desire.

But if it is intended that the organization be under an established form, then it may be well to have a check hist something like the following:

1. Powers. Here a wide spectrum exists. Many districts will be found to have extremely broad recitals as to their purposes and powers. But as all districts or public corporations are creatures of the legislature and have only those powers specifically given them, or reasonably necessary to the performance of specified functions, a close examination of the language of the statute itself is in order.

2. Area. On what basis are the boundaries drawn? Is it a necessary finding that included land will be benefited? May county or city boundaries be disregarded? Need included areas be contiguous? 
3. Who Shall Constitute the Legislative Body? The usual choice is between an autonomous board elected from divisions or at large and the county board of supervisors, acting ex-officio. If it is to be an autonomous board elected from divisions, how are the division boundaries determined? Do the directors cast weighted votes?

4. Who are the Voters? Shall they be all of the electors or shall they be landowners only? In the latter event, shall their votes be uniforn in value or shall they be weighted according to some such formula as the acreage or assessed value of their land?

5. Financing. If the money needed for the district's support is to be derived from an ad valorem tax, shall this bear on land alone, or land and improvements, or all property? What is the proper limit? Shall the district be empowered to incur bonded indebtedness; and if so shall there be provision for zones of benefit or improvement districts within the parent body? Is there power to issue revenue bonds?

6. Federal Cooperation. Having the power to cooperate and contract with the United States may be essential to a district's program.

7. Eminent Domain. There is no uniformity here. It is well to insure that the power be adequate to the anticipated work of the district. The right to take immediate possession pending suit to condemn may be desired. Here you will consult the language of the California constitution, ${ }^{64}$ rather than that of the statute itself.

The foregoing is not intended as a guide, but merely as illustrative of some of the considerations which will influence the practitioner who may be called upon to advise a group which desires to organize a water district. The task in such an event will be enormously simplified by the use of two analyses of water district statutes prepared by able public servants in Sacramento. These are "General Comparison of California Water District Acts," 55 and "Analysis of California District Laws."

\section{IV}

\section{UNITING EXISTING DISTRICTS FOR A COMMIN PURPOSE}

It seems probable that a great deal of the water management work which we can perceive in the future will be done by two or more districts or other public agencies, working together. As public necessities in this field, particularly of water carriage over long distances, grow in magnitude

64 CaI. Const. art. I, $\S 14$.

o5 Cal. Dep't of Public Works, Div, of Water Resources, General Comparison of Cartrornia Water District Acts (1955).

56 Cax. Assearbly Intertar Comonattee on Municipar and County Governament, Anatysis of CALIFoRNIA District Laws (1954). This study, by Deputy Legislative Counsel Kent L. De Chambeau, has been extended by a mimeographed pamphlet dated May 1956. 
and expense, it will become more and more advantageous for existing bodies to unite their resources, both financial and political, in the interest of a mutually beneficial plan. There are three general methods by which a cooperative union of this kind may be secured: one is by use of a joint powers agreement; another is by use of one of a number of general acts; and the third is by securing enactment of special legislation.

The Joint Exercise of Powers Act, sometimes called the "Joint Powers Act," ${ }^{67}$ dates from 1949. It permits public agencies to agree to join in the exercise of any power common to them and to contribute funds to the coinmon agency agreed upon. The agency which the parties agree shall act for them all may be one of the contracting agencies or may be a speciallyconstituted commission or board. In any event, such an agency is declared to be separate from the parties to the agreement. This may be entirely sufficient for the function the cooperating agencies wish to perform. A difficulty will arise, however, where it is desired that the representing agency shall have and exercise a power or powers not common to all the prospective parties. In that event the next step will be to search for an appropriate general law.

There are three statutes which may be found useable. In chronological order of enactment they are:

1. Municipal Utility District Act. This statute was enacted in $1921 .^{58}$ Districts formed under it have, among other purposes, that of supplying water to individuals and public agencies within their boundaries. Section 11561 of the Public Utilities Code declares that a municipal utility district may be formed by two or more public agencies as well as by a single public agency plus unincorporated territory. Such public agencies need not be in the same county nor need they be contiguous. Public agencies are restrictively defined in this act and in the one to follow, that is, by nueans of a list of particular kinds of districts and mumicipal corporations by name.

2. Metropolitan Water District Act. This statute was passed in $1927 .^{59}$ The only metropolitan water district in the state is the very large one in the Los Angeles area. As in the Municipal Utility District Act it will be necessary to consult the definitions to see whether the public agencies which are eligible to join under it include the particular public agencies which may desire to do so.

3. County Water Authority Act. This statute was passed in $1943 .^{60}$ It is inclusive, rather than exclusive, in its definition of public agencies which nay join, requiring only that, in effect, the prospective member districts or municipal corporations have power to acquire and to distribute water. The

\footnotetext{
67 CaI. Govt. Code $\$ \S 6500-78$.

58 Cax. Pub. UT. Code $\S \S 11501-4509$.

591 Car. WATER Code ANN., act 9129 (Deering 1954), as amended (Supp. 1957).

601 Car. Water Code ANN., act 9100 (Deering 1954).
} 
authority, when created, is a new body, distinct from its members, who suffer no diminution of power or loss of identity by joining. It may assess taxes, within a stated limit, and it may bond itself by the usual two-thirds vote. Its powers and purposes will cover nost projects having to do with a water supply, except that the authority may not acquire water or water rights within the county in which it is organized. That limitation and the further fact that the act contemplates the joining of agencies within a single county only would make this general act inappropriate in some situations.

$\therefore$ If no general act will do, a special one must be drafted. This may become the more usual method of uniting existing districts for a common purpose. In any event, the three general acts I have mentioned have had to date a total of only ten users ainong them. Eight of these are municipal utility districts, ${ }^{61}$ to which we may add the Metropolitan Water District of Southern California and the San Diego County Water Authority as the single creations under their respective statutes.

The special acts have taken a variety of forms. For exainple, in 1945, Santa Barbara County chose to organize under special legislation into a "Water Agency." ${ }^{62}$ Districts or municipalities lying within the county and having the power to appropriate and to distribute water could become "member units" by contract with the agency. The county board of supervisors was designated to act as, ex-officio, its board of directors. The Sacramento County Water Agency Act, ${ }^{63}$ passed in 1952, differs in no important particular from the Santa Barbara form.

A new principle was introduced in 1955 by the passage of the "Santa Clára-Alanieda-San Benito Water Authority Act" o4 which was specifically designed to assist the named counties in the problem of water importation. Here the authority, as an entity, is declared creatable by popular vote in existing water districts in the three counties and the area of the authority is the area of the districts, not necessarily contiguous, which join it. Districts in any county can join after initial incorporation. The powers and purposes; as also the general mode of acting and taxing, are patterned closely after the County Water Authority Act, which has been mentioned. ${ }^{05}$ It will be noted that the new feature of the "Tri-County Authority Act"as' the legislation very soon came to be termed-is the disregard of artificial, political boundaries in defining the proposed area of inclusion. It was thought, rather, that the authority should have the power to embrace an

${ }^{61}$ Cax. Dep't of Public Works, Div. of Water Resources, Generat Compparison of Catrformia Water District Acts 14 (1955). 1954).

${ }^{62}$ Santa Barbara County Water Agency Act, 1 Cax. WATER Code ANN., act 7303 (Deering

631 Cat. Water Code ANN, act 6730a (Deering 1954).

641 CAL. WATER Code ANN., act 9102 (Deering Supp. 1955).

651 Cat. Water Code ANiv., act 9100 (Deering 1954). 
entire region, the common needs and problems of which might lead the water districts therein to unite under it. The foreseeable growth in the absolute necessity of water transfers in much of the state invites the prophecy that the future evolution of California water users organizations nay he in the direction of coalitions of this kind. 